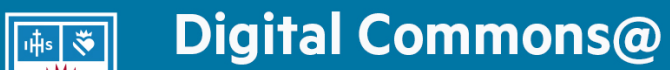

Loyola Marymount University

LMU Loyola Law School

\section{Journal of Catholic Education}

September 2015

\section{Educating for Social Justice: Drawing from Catholic Social Teaching}

James R. Valadez

University of Redlands

Philip S. Mirci Dr. (Ph.D.)

University of Redlands

Follow this and additional works at: https://digitalcommons.Imu.edu/ce

Part of the Educational Leadership Commons, and the Social and Philosophical Foundations of Education Commons

\section{Recommended Citation}

Valadez, J. R., \& Mirci, P. S. (2015). Educating for Social Justice: Drawing from Catholic Social Teaching. Journal of Catholic Education, 19 (1). http://dx.doi.org/10.15365/joce.1901072015

This Article is brought to you for free with open access by the School of Education at Digital Commons at Loyola Marymount University and Loyola Law School. It has been accepted for publication in Journal of Catholic Education by the journal's editorial board and has been published on the web by an authorized administrator of Digital Commons at Loyola Marymount University and Loyola Law School. For more information about Digital Commons, please contact digitalcommons@lmu.edu. To contact the editorial board of Journal of Catholic Education, please email JCE@nd.edu. 


\title{
Educating for Social Justice: Drawing from Catholic Social Teaching
}

\author{
James R. Valadez and Philip S. Mirci \\ University of Redlands
}

This article uses a duoethnographic process to develop a model for socially just education based on social justice theory and Catholic social teaching. Three major issues are addressed, including: (a) the definition of socially just education, (b) explaining a vision for establishing socially just schools, and (c) providing a practical guide for educational leaders to promote social justice ideals. The authors propose a vision for socially just education that calls for schools to instill social justice virtues into young people, much as one would instill wirtues such as morality, honesty, and fairness. As Pieper (2003) declared: "the good [person] is above all the just [person]" (p. 64).

\section{Keywords}

social justice, educational justice, Socratic dialectic, Catholic social teaching, duoethnography

$t$ the heart of developing an educational model for social justice is the
promise of creating an educational experience dedicated to providing
full and equitable opportunities for all students. Unfortunately for U.S. students, society has not delivered on that promise, and gaps in achievement persist between privileged and disadvantaged groups in communities throughout the country. The disparity in educational opportunity is significant, because it prevents students from reaching their potential, and reduces the opportunity for individuals to participate fully as citizens in a democratic society.

This article seeks to offer a socially just education model that has significance for Catholic school leaders, but would certainly be relevant for all schools. The authors base their thinking on recent developments in social justice theory but more significantly derive their ideas from the tenets of Catholic social teaching (CST).

We (James and Phil) argue in this article that schools steeped in social justice develop individuals not only capable of achieving their educational goals, but also equipped to address injustice in society and dedicated to promoting the common good. Because education is the primary vehicle for

Journal of Catholic Education, Vol. I9, No. I, September 2015, 155-177. This article is licensed under a Creative Commons Attribution 3.0 International License.

doi: $10.15365 /$ joce.1901072015 
enabling individuals to attain their goals, society depends on students having the opportunity to achieve that promise through an institution that "allow(s) social groups and their individual members thorough and ready access to their fulfillment" (Paul VI, I965, 26). We contend that the provisions of a socially just education allow such a possibility to be achieved.

Central to our strategy for conceptualizing a socially just model was using dialectical engagement to discern differing perspectives while employing intellectual humility to allow for the possibility of arriving at a shared understanding of social justice. Such engagement included acknowledging the social and cultural influences that shaped our perspectives of the external world.

We used a duoethnographic method over the course of an academic year for the purpose of addressing social justice within a Catholic educational context. We found this method useful for providing a structure for our various interchanges and discovered that it enabled us to reflect critically on our social justice beliefs and actions. We provide an explanation of the method in the following section.

\section{A Duoethnographic Approach}

In Plato's Symposium (trans. 2005), Socrates, along with several invited guests, gathers at Phaedras's house to give praise to the god of love (Eros). Generally speaking, symposia, or drinking parties, gave the revelers a chance to expound on a particular topic. At this symposium, Socrates wished to approach his speech differently and asked Phaedras if he could present a simplified speech without the sophistic oratory expected at such functions:

I am ready to speak in my own manner, though I will not make myself ridiculous by entering into any rivalry with you. Say then Phaedras, whether you would like to have the truth spoken about love, spoken in any words and in any order which may happen to come into my mind at the time. (trans. 2005, p. 9I)

Phaedrus consented to this request as well as to Socrates's further request that he might question the previous speaker, allowing him to clarify and hone his own speech. Socrates proceeds to question Agathon to shape his conception of true love as a transcendent pursuit of the good and the beautiful.

This brief synopsis exemplifies Socrates's method of probative questioning-the very essence of the Socratic dialectic method. The dialectic method 
is meant to encourage individuals to challenge positions, leading them to query the assumptions of a given argument. It exposes ideas and forces individuals to develop their standpoints using careful and logical reasoning. In the context of this article, we defined logical thinking as a disciplined process of critiquing and analyzing discourse to arrive at a reasoned position. The intention of the method is to arrive at a synthesis of thinking composed of well-reasoned arguments. In a similar spirit, we (James and Phil) attempted to use a dialectical process to challenge historical and current perceptions of social justice and to discuss applications of social justice to educational practice.

The dialectical approach we followed in this study was based on the epistemological understanding that meaning is socially constructed. Cranton (1994) has explained that the social construction of knowledge comes through social interaction leading to a better understanding of an individual's standpoint through a "group process of active meaning-making [using] dia$\log$ " (p. 23r). We developed a set of procedures based on the work of previous researchers who used a collaborative or joint process of data collection and analysis. Each of the researchers emphasized discussion between and among individuals, interplay of ideas, and the joint development and refinement of concepts. The procedures we followed for designing the study were drawn from Marine and Nicolazzo's (2014) work on duoethnography, Kvale’s (200I) discussion of dialectical research, and Feldman's (1999) concept of conversation as research.

Marine and Nicolazzo (20I4) have described duoethnography as two researchers challenging each other's position, leading to revision or reconceptualization of the topic. Previously, Feldman (1999) had argued that conversation provided a pathway for researchers to explore ideas and reach new understandings. He explained that conversation also served as a means of shaping responses and directing the conversation in a dialectical process, describing it as moving back and forth beginning with a preliminary understanding of an issue and eventually leading to a more insightful understanding of the concepts being discussed. Kvale's (200I) proposal was that qualitative interviewing based on Socratic dialectic methods served as a joint search for knowledge. In Kvale's (200I) scheme, a dialectical process surmounts the asymmetrical power dynamics in many qualitative interviewing sessions. In traditional qualitative interviewing, the researcher-participant dyad is often complicated by the status differential in the relationship, as the interviewer may inadvertently impose his or her knowledge on the participant or unilat- 
erally set the agenda without creating space for the participant to ask questions or challenge the interviewer during the session. In a dialectic model, on the other hand, according to Kvale (200I), the give and take of the Socratic method encourages an equal partnership and affords an egalitarian power distribution in the relationship. In this alliance, both parties pose questions and give answers and establish an opportunity for the participant to question or offer critique in order to contribute actively to the developing narrative.

\section{Context for the Study}

Although there are many similarities in our backgrounds, our particular worldviews led to our own development as social justice leaders and educators. To provide some context for the development of our ideas, we furnish here some background on our own histories and trace the origins of our views. Both of us have long histories of commitment to social justice. Phil's background includes four years of seminary study and ordination as a Roman Catholic deacon. His life experiences have involved working with the disenfranchised and the marginalized. Over the past six years, he has balanced his work as deacon with his position as a faculty member at the University of Redlands, where he teaches social justice and foundation courses. In his classes, he seeks to provide learning experiences whereby participants challenge their own unexamined assumptions and engage in transformative learning. Influenced by Catholic social teaching, he formed his conscience around social justice issues-although, in his view, his seminary training led him to be a critical thinker and has encouraged him to engage in studying the diversity of Catholic theological positions.

James's experience is quite different. James developed his social conscience through numerous studies of disadvantaged populations including his writings on impoverished African American women in the rural south (Valadez, 2000), Mexican immigrant students in the Yakima Valley (Valadez, 2008), and working-class community college students in various settings (Rhoads \& Valadez, I996; Shaw, Valadez, \& Rhoads, r999). James has spent his professional career as an academic, teaching and researching topics germane to principles of social justice. In his former position as dean of a school of education, James's goal was to further the cause of social justice by assuring its central place in the school's curriculum, and by intentionally articulating the school's mission in public forums throughout the community. At the times of this study, James, much like Phil, is an active member of the Catholic Church 
and does not believe his social justice position is at odds with the Magisterium of the Church.

While the authors' professional paths were markedly divergent, their early formation of both was steeped in social justice activity. As Catholics, both came of age during the nascent post-Vatican II world. James was educated in Catholic schools, where he was exposed to a practical implementation of social justice by the Christian Brothers, a teaching order that stresses simplicity of life, piety, and service to the poor. Phil attended public schools, but from an early age was involved in church work such that social justice has been a lifetime pursuit, culminating in his pursuit of a theological degree.

At the outset of the post-Vatican II era, James and Phil were both influenced by the Church's reawakening to social concerns. John XXIII's writings, an intellectual impetus that presaged the Vatican II movement, proved to be highly influential in shaping the Church's recommitment to social ideals. In particular, the encyclical Mater et Magistra (John XXIII, 196I) redefined the Church's commitment to the service of the poor. The Pope's admonitions to believers was that the

Church's first care must be for souls, how she can sanctify them and make them share in the gifts of heaven, [but] she also concerns herself with the exigencies of man's daily life with his livelihood and education, and his general temporal welfare and prosperity. (para. 3)

We interpreted John XXIII's message as a challenge to the economic status quo. We recognized that he was deeply concerned with the division between rich and poor and agreed with his call for "public authorities responsible for the common good [to] intervene in a wide variety of economic offices" (para. 54). Pope John XXIII promoted the notion that government plays a key role in assuring common dignity for its citizens and promotes an ethos of brotherhood for society.

John XXIII's message of human dignity was also directed at a world concerned with the Cold War conflict and the fears associated with Soviet domination of Eastern Europe. The release of the encyclical Pacem in Terris (1963) coincided with the construction of the Berlin Wall and focused attention on the public's anxiety over preserving human rights and liberties. Recognizing the public's fears, John XXIII wrote that "[All humans have] the right to bodily integrity and to the means necessary for the proper development of life" (para. II). 
In our discussions, we recognized that these two encyclicals (Pacem in Terris [1963] and Mater et Magistra [196I]) acted to further the teachings expressed in Pope Leo XIII's Rerum Novarum (I89I), and all three served as bellwethers for the Church's renewed commitment to social justice. Pope Leo XIII wrote:

Man should not consider his material possessions as his own, but as common to all, so as to share them without hesitation when others are in need. Whence the Apostle with, "Command the rich of this world... to offer with no stint, to apportion largely." (para. 22)

Whereas one may consider the post-Vatican II era as an affirmation of Leo XIII's concerns regarding the exploitation of the working class, this movement was, in fact, a return to the roots of the Hebrew patriarchs, who called for a covenant of love and justice (Leviticus I9:I8; Isaiah, 58:7 New Revised Standard Edition). It was a teaching reflected in other scriptural writings, beckoning believers to "bring glad tidings to the poor...liberty to captives... [and] recovery of sight to the blind (Isaiah 6r; Luke 4:I8-I9). In a Church recommitted to the needs of the working poor, we developed our initial motivation to strive toward social justice ideals. We anchored our ideals in the teachings of Christ as he was portrayed in the Gospels as an example of the universal appeal for the love of others.

In the brief sketch above, we described the context that shaped our early formation as advocates for justice. Even though our early development featured similar experiences, our later intellectual and career paths diverged. What these diverse paths indicated, however, was that although our theoretical frameworks, intellectual discourses, and philosophical positions did not always coincide, the commitment of dedicating our professional lives to guiding the poor to overcome oppression remained central to our lives. The convergence of our paths that led to the synthesis of our ideals is the focus of this article.

\section{Procedures}

To be specific about our procedures, we, as researchers investigating social justice, met in various settings, over meals, and casually in our offices to discuss our views on the composition of a socially just education. As a starting point, we considered various definitions of social justice. We agreed that 
although individuals may arrive at varying opinions regarding social justice, we accepted that social justice provides a framework for social critique with particular utility for examining the unequal distribution of wealth, power, and opportunity that characterizes U.S. society. It was our contention that the various conceptions of social justice may be derived from individual constructions of the concept, leading to disagreement and varying perspectives. As Cranton (1994, p. 28) has described, individuals' perspectives are "based on the way they see the world, their cultural background and language, psychological nature, our moral and ethical views, the religious doctrine or world view we subscribe to, and the way we see beauty."

In our discussions, we considered the possibility of creating schools with social justice principles at their core. This idea led to the initial development of a draft (without the recommendations), which we shared and revised; then we met again to discuss the revisions. We continued this iterative process over a period of nine months until we reached saturation. When we found that any new information collected or revisions to the document did not contribute substantially to the developing narrative, we followed Corbin and Strauss's (1998) guidance concerning saturation. We recognized that the primary focus of a dialectical exchange was to establish a framework with the potential for influencing social change in our schools. Although our goal was social change, we settled on the premise that the dialectic at this stage would not lead to a definitive plan but would form the basis for initiating an ongoing discussion on transforming schools. We do not presume to have the answers but look forward to the critique and contributions of other researchers and educators to our framework. Our premise was that dialectical research can only be successful if we followed Freire's (1996) example by practicing humility and arriving at the understanding that no single individual is the owner of the truth.

In what follows, we jointly offer our own development and formation as educators and leaders who consistently invoked a concept of social justice. We present and critique the theoreticians, practitioners, and scholars who influenced our positions, and in the end we offer a confluence of our thinking on what constitutes a socially just education. In a more practical vein, we expect that this exercise will provide a framework for educational leaders to examine their practice and promote the development of schools modeled on democratic principles. To provide a guidepost for this discussion, we selected three general questions: 
I. What is known about social justice, and how is it defined?

2. What is the authors' vision of a socially just education?

3. How should educators dedicated to social justice encourage education leaders to promote social justice in $\mathrm{K}-\mathrm{I} 2$ education?

\section{Background on Social Justice}

The phrase social justice can be traced to Luigi Taparelli, a nineteenthcentury Jesuit priest. Taparelli used it to describe a means for society to overcome problems associated with poverty and oppression through societal cooperation and intervention by the State ("Luigi Taparelli," 2012). This particular approach contributed to the perception that social justice was rooted in socialist ideals and was determinedly anticapitalist. As a result of the antipathy leveled at educators who embraced the ideals of social justice and the general debate emanating from the controversy, the term is often loosely defined and misunderstood. In general, the varying interpretations and definitions of social justice do not always include its theoretical, moral, or ethical foundations. These issues, of course, should be central to social justice, particularly as it applies to education. It was critical to our discussion that we considered these issues as we sought intersections and agreements in our own perceptions of social justice.

Although the overall goal of a socially just education — namely, striving for equality of opportunity for all individuals - is generally agreed upon by scholars and practitioners. What has been missing in the social justice literature is theoretical clarity. Rawls's (I971/1999) liberal theory was a pioneering attempt to address the theoretical paucity of social justice literature and discourse by focusing on the role of individual liberty in the pursuit of an egalitarian society. According to his principles, society would provide conditions needed for individuals to achieve the good life, and cooperating governmental agencies would work toward eliminating inequality in society.

Beattie (1982) found that Rawls's position applied to education because of his view that the "task of education... is to try to even things out... [and] given disparities in ability, [how] education resources can be distributed so as to help improve the lot of the least favored" (p. 4I). The liberal viewpoint was a significant force in federal education policymaking in the ig6os. In particular, policies that sought educational equality through the implementation of structural changes in schools shaped the prevailing views of decision makers. As an example, strategies to achieve racial balance in schools (including 
busing) were widely implemented. Without question, dismantling segregated school systems was a laudable goal, but the various structural solutions did not lead to the expected outcome of achieving educational equality. Critics assailed the presumption that equality could be achieved by engineering social change without first tackling fundamental problems of racism and classism. Busing children from previously segregated schools to schools in White neighborhoods only partially contributed to the effort to improve minority children's achievement or close the gap between White children and minority children.

North's (2006) review traced the theoretical development in social justice education. She began her review by questioning longstanding liberal assumptions, citing the absence of sociopolitical and sociohistorical content in the discussion of social justice in education. North (2006) cited this lacuna as a central weakness of Rawls's position and noted that recognition and respect for the contributions and perspectives of various social and ethnic groups is a necessary part of a socially just education.

Several scholars (i.e., Cochran-Smith, 2006; Lynch \& Baker, 2005; Young, 1990) also critiqued Rawls for his presumption regarding the neutrality of schooling. Other challengers (Kymlicka, I995; MacIntyre, 1989; Taylor, 2007) to the Rawlsian view cited the flaws in the argument that equality could be achieved through the redistribution of resources. Wolff (2002) identified Rawls as an apologist for the status quo who failed to expose capitalism as an exploitative system responsible for creating a perpetually unjust world. Additional criticism from the left came from feminists-in particular Okin (1989) — who noted that Rawls failed to recognize that society's embedded patriarchal system was a factor in social injustice. These and other contemporary scholars of social justice education distanced themselves from traditional liberalism and emphasized critiquing the power and status relationships extant throughout society, the effects of globalization and capitalism on world affairs, and historical perspectives on oppression of the poor (Apple, 2004; Giroux, 1983).

Lynch and Baker (2005) contributed to social justice theory by focusing on the role of affect in the education of children. They were critical of classical liberal education that promoted the development of rational viewpoints (in the narrow sense) and the emphasis on preparing individuals for economic advancement in the public sphere. Public education, in their view, ignored the importance of the development of individuals as relational, interdependent "other-centered" human beings. Etzioni's (2004) communitarian posi- 
tion emphasized the importance of developing interpersonal relationships and fostering community. He posited that schools have the responsibility to develop a moral framework emphasizing civil, caring relationships. Etzioni (2004) and Kersbergen (1995) sought to promote schools as agents of transformation, with an emphasis on developing the moral values leading toward a unified society dedicated to working together and emphasizing the primacy of civic duty, stewardship, and cultural pluralism.

Etzioni's (2004) communitarism has much in common with Catholic social teaching as defined by the United States Conference of Catholic Bishops (USCCB). In their Catholic Framework for Economic Life (USCCB, I996), the Bishops implicated a global culture driven by excessive individualism as a responsible agent for the persistent and growing division between rich and poor in society. The bishops proclaimed that whereas individualism is a value promoted by U.S. society, Catholic tradition teaches that human beings grow and achieve fulfillment through their participation in cooperative communities (USCCB, n.d.). CST emphasizes that people have a right and a duty to participate in society and to work together to achieve the common good and well-being of all, especially the poor and dispossessed (USCCB, I986). The centrality of this concern is much in evidence in the writings of Thomas Aquinas:

If we love our neighbor only to the extent that he can be of use to us, then surely we are not loving him, much less loving him as loving ourselves...charity proceeds from a pure heart and a good conscience... Good will strives effectively in act and work to see that good comes to him and that evil be turned away or relieved. (As cited in Clark, 1972, p. 28I)

Catholic Social Teaching refocuses attention away from traditional liberal solutions (Rawls's redistributive model) for combatting poverty toward social critique that addresses the root causes of oppression and the disenfranchisement of the poor in U.S. society. Its focus on community and its concern for the needs of the "other" in society is in line with social justice principles seeking to develop individuals with a concern for our neighbors and a commitment to justice and fairness.

As noted above, North (2006) critiqued social justice models that undervalued the social contributions of the nation's oppressed groups. She observed that extant liberal models have ignored the lingering legacy of racism, sex- 
ism, and classism that have subverted the full participation of marginalized groups. Her point was that liberal theorists (Freeman, 2006; Rawls, 197I/I999) argued for the establishment of a "color blind" society that blurred the existence of racial distinctions and avoided confronting issues of social and racial prejudices. In North's (2006) view, ignoring these issues only caused them to fester and perpetuate.

Contemporary scholars (Banks, 2007; Gay, 20Io; Ladson-Billings, 20or; McLaren, 1995; Sleeter, 200I) have focused on transforming racist attitudes and eliminating the harmful effects students experience in schools that are intolerant of their cultural backgrounds. Addressing inequities in schools must begin by transforming schools into places where all cultures are welcomed and students do not endure disadvantages because of their cultural background. Eradicating the privileging of dominant cultures would serve to honor and recognize the cultures of marginalized groups, leading to the creation of a just and democratic society (Taylor, 2007). In Freirian terms (Freire, 1996), individuals are transformed and, in the end, strive for a higher social consciousness firmly dedicated to the cause of overcoming educational injustice.

What we have presented above represents the complex origin and frequently contested perspectives that social scientists, educators, and the Catholic Church have used to describe social justice. In what follows, we use dialectical principles to craft our vision for social justice education. We do not expect this discussion to be conclusive, but rather intend it to stimulate further debate about what these principles mean for educational leaders.

\section{The Dialog Ensues}

In Plato's rhetorical style, he chose not to reject particular views, but used his dialogs to construct deeper and more incisive meanings of a concept. In our dialog, we applied the duoethnographic technique by posing several sides of a topic and compared and contrasted the viewpoints from various perspectives. As an example, James recalled (J. Valadez \& P. Mirci, recorded discussion, September 29, 2013) the relevance of God's greatest commandments (Mark I2: 30-3I) toward the formation of social justice principles:

And you shall love the lord your God with all your heart, and with all your soul, and with all your mind, and with all your strength. The second is this, you shall love your neighbor as yourself. There is no other commandment greater than these. 
James posed that these commandments set the stage for the ethic of care that underlies social justice principles. This proposal stimulated Phil and James (J. Valadez \& P. Mirci, recorded discussion, September 29, 2013) to recount Saint Paul's letter to the Corinthians (I3:4-8, I3):

Love is patient, love is kind. It does not envy, it does not boast, it is not proud. It does not dishonor others, it is not self-seeking, it is not easily angered, it keeps no record of wrongs. Love does not delight in evil but rejoices with the truth. It always protects, always trusts, always hopes, always perseveres. Love never fails. But where there are prophecies, they will cease; where there are tongues, they will be stilled; where there is knowledge, it will pass away. And now these three remain: faith, hope and love. But the greatest of these is love.

The discussion led to our proposition that Paul's letter was foundational for the subsequent development of early Catholic principles for a just society (J. Valadez \& P. Mirci, recorded discussion, September 29, 2013). Our contention was that an education built on social justice ideals derived its principles from well-established Hebrew and Christian scriptural doctrines of love, justice, and mercy, later refined by early Christian disciples and scholars. Paul's themes of fairness and selfless devotion formed the basis upon which later philosophers and theologians built their own concepts of a just society. Certainly Aquinas's principles, rooted in Saint Paul's teachings, exemplified this vision of justice, mercy and charity. In Summa Theologica, he expressed the view that:

God acts mercifully, not by going against His justice, but by doing something more than justice, thus a man who pays another two hundred pieces of money, though owing him only one hundred, does nothing against justice, but acts liberally or mercifully. The case is the same with one who pardons an offence committed against him, for in remitting it he may be said to bestow a gift. (Aquinas, trans. I920, I.3.2)

Aquinas's views on justice, mercy, and charity established criteria for creating a just and loving world. According to Aquinas, individuals share the responsibility for assuring that their neighbors achieve a good and dignified life. Indeed, contentment and satisfaction with life depend on the general well-being of a community. This belief aligns with Etzioni's (2004) communi- 
tarianism, in which the growth, development, and well-being of a community depend on the contributions and caring acts of the family, our neighbors, and the larger social world. In this system, whatever is good or harmful to one has an effect on others. For this reason, it benefits the community to enact, enforce, and sustain provisions that encourage members to support each other. This principle is the basis of a system of social justice that calls for individuals to serve and care for those in need. It strengthens the ability of all members of the community to produce positive values by bolstering the foundations of a civil society. In this respect, the virtues inherent in social justice are showcased in addition to the pragmatic value gained in rallying around our brethren.

In one of our reflections (J. Valadez \& P. Mirci, recorded discussion, January 13, 20I4), we posed that Catholic doctrine on social justice and the common good may seem out of step in a society that venerates individualism and appears to have little time for caring for its poor and dispossessed. Furthermore, we concluded that a transformation of this attitude would involve a process beginning at the microlevel of individual exchanges and eventually developing into whole communities abandoning current narcissistic trends toward self-promotion, an obsession with the acquisition of material goods, and the public's virtual acceptance of an overall degradation of moral values in society. A transformed society will move toward a commitment and devotion to the well-being of communities.

Etzioni (2004) suggested that consumerism, or the obsession with the acquisition of goods, is the organizing principle of American life. Communitarian ideals promote investing time and energy into relationships and a spirit that enhances the care and well-being of society in pursuit of the common good. A transformed society shares an understanding that caring and loving one's brethren contributes to the development of community, the betterment of our nation, and the creation of a socially just world. The motivation for pursuit of the common good depends on the moral development of the citizenry. This aim, of course, begs the question, how does society abandon its long-engrained culture of individualism, competitiveness, and materialism and assume communitarian ideals of love, justice, and mercy? The primary mechanism for achieving this transformation would come through a vision of education that promotes virtues characteristic of a socially just world. In the next section, we discuss the steps for achieving a socially just world and instilling in students the virtues needed for the commitment to transform society. 


\begin{abstract}
A Call for Virtue
We continued the duoethnographic process and attempted to address the second guiding question in order to discuss possible mechanisms for achieving a socially just world. Our discussion was directed to the power of individuals for promoting social change. It followed that reforming schools depends on individuals who carry the responsibility for educating children (parents, teachers, administrators) to recognize, discuss, and - when necessary-challenge the barriers that impede social progress and, ultimately, to replace them with new practices. In the case of a socially just education, individuals would emerge from their schools with a commitment to overturning policies and practices that disadvantage or marginalize oppressed groups in society. To address this point, we ( J. Valadez \& P. Mirci, recorded discussion, February Io, 20I4), discussed the development of a socially just curriculum:
\end{abstract}

James: The core of what we are proposing...comes from Catholic social teaching. I believe we are talking about values that we want to introduce in the curriculum.

Phil: It is more in the realm of ethics...social justice and an ethic of care that emphasizes the interdependence and the relational aspects... if that premise is accepted...I am talking about a culture of formation.

James: Yes, say more about that and how it applies to all schools.

Phil: When I talk about formation...it is integrated into the curriculum...it includes a method for showing students about how to use these principles. I am talking about how it guides one's life. It is a framework that guides decision-making.

James: So for instance, when we talk about leadership and teaching about leadership we are talking about ethical leadership and what it is to be an ethical leader. It is instilled and becomes a part of an individual's world view. These principles become central for our formation of socially just leaders. They are prepared to instill in their students the commitment for challenging oppression.

Phil: Yes, it is based on moving away from the status quo or the idea of preserving positions of dominance in society...It challenges...opposes the present order...It is talking about a way of improving society...an 
acceptance, recognition of marginalized groups, an inclusivity... that is a reflection of Jesus' meaning of universal love.

James: Yes, individuals prepared to work toward social change...leaders prepared to see their own role in making a difference.

Our discussion led to the view that individuals are the source of power for social change, even against perceived dominant forces that preserve the status quo. We cited examples of individuals in history who challenged the status quo to institute social change. Movements such as the civil rights protests of the r95os and I96os, the student activism of the r96os, and the Occupy Movement of 20II-20I2 grew out of individual experiences and everyday grievances. The movements emerged from the depths of injustice, developing into lunch counter protests, public transportation strikes, student sit-ins opposing the Vietnam War, and groups of disaffected individuals fed up with Wall Street corruption. These are examples of individual participation in democratic processes that eventually grew into large-scale social movements leading to either historic policy changes or broader public awareness of the issues.

Recognizing the power of the individual to institute social change, we proposed, through our dialectic process, a model of education that would move beyond its current functionalist obsession with high-stakes testing toward an institution created to instill virtues in individuals that would equip them with the skills and knowledge to pursue and form dispositions to do good (Catechism of the Catholic Church, 20II). The focus on the moral development of individuals would involve a cooperative approach involving family, school, and community, all collaborating to instill the virtues our students need to establish and sustain a just and merciful world. Our dialog below (J. Valadez \& P. Mirci, recorded discussion, June Io, 20I4) exemplifies the duoethnographic principles we used for posing a view and being open to questions and challenges regarding the need for including an emphasis on moral development in our schools:

James: It is a shift...It is an emphasis away from individualism and the recognition of the existence of the "other." It is missing in our society.

Phil: We can look at opportunities for ethical formation in the curriculum and provide for students an opportunity for exercising generosity, think about human needs and spark some thinking. 
James: I see...In this way they develop a means for moral reasoning as they sort through complex problems. They learn to discern. We give them the opportunity to serve and practice generosity. When we talk to them, we examine who they've come in contact with... what they've learned.

Phil: They discuss the morality of current school practices...

James: Yes, I think an example is examining schools and their practices. Schooling is often oppressive and they use authoritarian practices to control. I think testing is an example. How testing is used and how it controls.

Phil: Especially the consequences of testing...the sanctions they receive. Who do these sanctions affect...the very poor and impoverished schools who do not meet standards.

Our discussion was critical of schooling practices, but it also recognized the school's primary responsibility for ensuring that students graduate with the ability to read well, compute competently, and write correctly. We believe that, beyond assuring that students attain those skills, educational institutions have a role in producing students who learn the "best way to live" in society (MacIntyre, 2007). Implicit in this judgment is that the "best way to live" promotes an education extolling democratic values of fairness and justice. It is our contention that individuals must receive the kind of education that will prepare them to make contributions for the benefit of humankind. If individuals are not adequately prepared to live by social justice principles, there is little reason to expect that society will realize the transformation envisioned by the authors. We view this model of education as the development of an institution dedicated to instilling virtues into young people, much as we would instill virtues such as morality, honesty, and justice. As Pieper (2003) declared: "The good [person] is above all the just [person]" (p. 64). Following this view rooted in Catholic social teaching, we use the next section to provide our practical recommendations for creating socially just schools.

\section{Recommendations for a Socially Just Model of Schooling}

The results of our duoethnographic discussions set the stage for us to address the third guiding question. Based on our earlier recorded discussions and the draft of our manuscript, we met to generate recommendations for 
developing a socially just model of schooling. We discussed the manuscript and generated a set of recommendations (J. Valadez \& P. Mirci, recorded discussion, June, 18, 20I4). After reviewing and exchanging drafts of the recommendations over a period of several weeks, we settled on a list of ıo, listed below. We agreed that of all the recommendations a call to virtue was most important and should be listed first. The other nine are not listed in any particular order of importance.

\section{A call for virtue}

Our first recommendation derives from the major premise of this article: schools must work actively to promote socially just virtues in the daily lives of their students. This effort would be exemplified in a curriculum that provides opportunities for students to practice generosity by working with those in need. Through this curricular transformation, students will be able to show their commitment to the virtues of love and justice. We agree with Pope Benedict XVI's view that "closing our eyes to our neighbor also blinds us to God" (2005, para. 16). This notion is in line with the Catholic sentiment that love is a beacon for a world grown dim with selfishness and greed and will provide us the will to work toward the development of students with the missionary zeal to achieve social change.

\section{Involving stakeholders (school administrators, teachers, parents) in discussions that deconstruct the purpose of schooling}

We base this recommendation on the idea that expecting school reform without including the voices of the stakeholders and respecting their particular worldviews regarding the purpose of schooling would be ineffectual for achieving social justice aims. The process begins by including the perspective of stakeholders as they examine and make sense of educational reality-in particular, challenging the established authoritarian practices of educational institutions and what Freire (1996) has famously called the "banking model of education." Our critique interrogates other authoritarian policies, including the inequitable imposition of punitive practices (school sanctions, student suspensions, and expulsions) that disproportionately affect minority and poor children.

\section{Shifting from standardization to personalization}

Gary Marx (2006) suggested that standardization has taken over education at the cost of relevance to the lives of students. To illustrate, standardized 
testing dominates and controls practices in schools and often marginalizes poor and minority students. Sacks (1999) has implicated school administrators in the tendency toward "branding those who score poorly on standardized tests and labeling them as deficient, incapable" (p. 5). We advocate halting what amounts to the incursion of standardized tests into student lives and moving toward the inclusion of authentic or project-based assessments as a more personalized model of education.

\section{Creating schools that are liberating}

Freire (1985) has described a liberating education as one that promotes a willingness to be critical and even to have doubt about one's own assumptions regarding educational practices. The key component in a liberating education is an emphasis on dialogue. This model is meant to eliminate "top-down" hierarchal models of educational practice. The purpose of infusing dialogue into pedagogical practice is to encourage the development of a co-equal relationship between teacher and student. Ideally, teacher-generated knowledge continues to be respected, but knowledge co-constructed with students is being more widely recognized and is gaining acceptance. This recommendation challenges educators to reflect critically upon their practice as a process of liberation and freeing children from the oppression of traditional schooling (St. John, 1999).

\section{Learning the difference between charity and social justice}

Charitable actions are good and often benefit society; for example, giving time and monetary resources to alleviate the suffering of the poor is a laudable virtue. Visiting the incarcerated to offer literacy classes is also an act of charity. In contrast, social justice involves striving to address the causes of poverty or working toward prison reform. Service learning provides an avenue for integrating social justice activism into a school's curriculum. A service learning experience provides students the opportunity to abandon superficial thinking, including stereotypical assumptions about the poor. It encourages students to foster a more complex perception of the world and to develop a more systemic view of the root causes of social injustice.

\section{Implementing a problem-posing pedagogy}

Problem posing focuses on power relations in the classroom. It offers all subject matter up as historical evidence to be pondered rather than as univer- 
sal wisdom to be accepted. The responsibility of the problem-posing teacher is to diversify subject matter and to use students' thoughts and speech as the basis for developing a critical understanding of unequal conditions in society. In problem-posing pedagogy, teachers are not filling empty minds with official knowledge but posing knowledge as a source for mutual inquiry (Shor, I992, pp. 32-33).

\section{Creating a school culture of inclusivity and cultural responsiveness}

Terrell and Lindsey (2009) have expressed the need for a school culture based on cultural inclusivity and responsiveness to discriminatory actions. They have advocated for a culture free of institutionalized racism, sexism, classism, ableism, ageism, and religious intolerance. Teachers, administrators, and parents need to act morally in pursuit of equitable and culturally responsive school environments, which means that adults who embrace and model social justice leadership are at the heart of the school culture.

\section{Creating conditions for a socially just education}

To implement a socially just education, educators must create positive conditions for learning. According to Cambourne (1988), if conditions are met in a positive way, students are more likely to believe that they have the potential to learn and succeed in the world. When educators create classroom and school cultures in which positive conditions for learning take place, they create the groundwork for encouraging student social activism.

\section{Guiding educators to be reflective practitioners}

Educators must be reflective practitioners (Schön, 1983). Critical reflection on a daily basis is necessary for educators to move beyond unexamined assumptions and uninformed beliefs that accompany an uncritical examination of society. Without such critical reflection, the tendency is to accede to the interests of the dominant culture.

\section{Io. Encouraging educators to become systemic thinkers}

The final recommendation is that educators become systemic thinkers capable of contributing to systemic change. Systemic —or ecological-thinking means that instead of examining smaller and smaller parts of the system in isolation, one takes a holistic view and accounts for the various interactions among parts within the system. This radically different perspective may result in the analyst drawing different conclusions than those expected in more 
traditional forms of inquiry. With this type of analysis, leaders move from applying "quick fixes" to a more complex view that takes into account all elements that contribute to the problem.

\section{Concluding Thoughts}

Jeff Dietrich (2014), in his book The Good Samaritan, captured our thinking regarding the importance of community and the interdependence of all individuals in society: "We are all one living organism and we are obliged to take care of each other, especially the poor, the vulnerable, and the victims" (pp. 169-I70). Dietrich's (2014) sentiment is in contradistinction to current attitudes and governmental policies that ignore and often discard those in need. Among those most in need, of course, are children living in poverty and attending schools that are failing to provide an adequate education. To us, the transformation of schools lies in the possibility of developing leaders who will respond to the needs of the poor through social justice principles. Our position is that the principles articulated by Aquinas lay the foundation for current social justice scholars to provide the framework for establishing a socially just education:

When a man does what he ought, he brings no gain to the person to whom he does what he ought, but only abstains from doing him a harm. He does however profit himself, in so far as he does what he ought, spontaneously, and this is to act virtuously. (trans. 1920, 2.3.I)

These principles equip individuals with the desire to act out of the common good so that they naturally feel the inclination to provide education to the poor. In this understanding of the common good, we accept the duty of "making ourselves a neighbor to the poor and actively serving them" (Catechism of the Catholic Church, 1932).

As a result of the duoethnographic process, we critiqued various perspectives on social justice, but in the end our discussions nearly always reconnected us to the ideals of Catholic social teaching. We found that our views coincided with those of Peter Maurin, the cofounder of the Catholic Worker (along with Dorothy Day), who believed that each person has infinite value and that our decisions must be made to protect their interests and to preserve the dignity of each human being (Day, I977). We wholeheartedly agree with Maurin, who repeatedly reminded us that people were not meant to live in humiliating poverty and, by extension, children were not meant to endure substandard and ineffectual schooling (Anglada, 20I4). 


\section{References}

Anglada, E. (20I4). The history and new growth of Catholic worker farms. America: The National Catholic Review, 2ro(I8). Retrieved from http://americamagazine.org/issue/ taking-root

Apple, M. (2004). Ideology and curriculum. New York, NY: Routledge

Aquinas, T.(1920). Summa theologica. In Fathers of the English Dominican Province (Trans.). The summa theologica of St. Thomas Aquinas (2nd/Rev. ed.). Retrieved from http://www.newadvent.org/summa/

Banks, J. (2007). Educating citizens in a multicultural society. New York, NY: Teachers College Press.

Benedict XVI. (2005, December 25). Deus caritas est. Retrieved from http://w2.vatican.va/ content/benedict-xvi/en/encyclicals/documents/hf ben-xvi enc 20051225 deus-caritasest.html

Beattie, C. (1982). Rawls and the distribution of education. Canadian Journal of Education/ Revue Canadienne de l'éducation, 7(3), 39-50. doi: 10.2307/I494694

Cambourne B. (1988). The whole story: Natural learning and the acquisition of literacy in the classroom. Auckland, New Zealand: Ashton Scholastic.

Catholic Church. (20II). Catechism of the Catholic Church (2nd ed.). Vatican: Libreria Editrice Vaticana,

Clark, M. (Ed.). (1972). An Aquinas reader. Garden City, NY: Image Books.

Cochran-Smith, M. (2009). Toward a theory of teacher education for social justice. In A. Hargreaves, A. Lieberman, D. Fullan, \& D. Hopkins (Eds.), Second international handbook of educational change (pp. 445-467). Houten, Netherlands: Springer Netherlands.

Corbin, J., \& Strauss A. (1998). Basics of qualitative research: Techniques and procedures for developing grounded theory (3rd ed.). Thousand Oaks, CA: Sage Publishers.

Cranton, P. (2004). Understanding and promoting transformative learning: A guide for educators of adults. San Francisco, CA: Jossey-Bass.

Freeman, S. (2006). The law of peoples, social cooperation, human rights, and distributive justice. Social Philosophy and Policy, 23(I), 29-68. doi:Io.IoI7/So26505250606002X

Freire, P. (1985). The politics of education: Culture, power and liberation. Westport, CT: Bergin and Garvey.

Freire, P. (1996). Pedagogy of the oppressed. New York, NY: Penguin.

Gay, G. (2010). Culturally responsive teaching (2nd ed.). New York, NY: Teachers College Press.

Giroux, H. (1983). Theory and resistance in education: A pedagogy for the oppressed. New York, NY: Bergin and Garvey.

John XXIII. (I96I, May 15). Mater et magistra. Retrieved from http://w2.vatican.va/content/ john-xxiii/en/encyclicals/documents/hf j-xxiii enc 1505196I mater.html

John XXIII. (I963, April II). Pacem in terris. Retrieved from http://w2.vatican.va/content/ john-xxiii/en/encyclicals/documents/hf j-xxiii enc IIO4Ig63 pacem.html

Kvale, S. (200I). The dominance of dialogical interview research: A critical review. Retrieved from https://www.ntnu.no/documents/I0458/r9132562/kvale3.pdf 
I76 Journal of Catholic Education / September 2015

Kymlicka, W. (1995). Multicultural citizenship: A liberal theory of minority rights. Oxford, UK: Oxford University Press.

Ladson-Billings, G. (200I). Crossing over to Canaan: The journey of new teachers in diverse classrooms. San Francisco, CA: Jossey-Bass.

Leo XIII. (I89I, May I5). Rerum novarum. https://w2.vatican.va/content/leo-xiii/en/ encyclicals/documents/hf 1-xiii enc 1505I89I rerum-novarum.html

Luigi Taparelli. (2012). In Encyclopedia Britannica. Retrieved from http://www.britannica.com/EBchecked/topic/1559350/Luigi-Taparelli

Lynch, K,. \& Baker, J. (2005). Equality in education: An equality of condition perspective. Theory and Research in Education, 3(2), I3I-I64. doi: ro.II77/I477878505053298

MacIntyre, A. (2007). After virtue: A study in moral virtue (3rd ed.). Notre Dame, IN: University of Notre Dame Press.

Marine, S., \& Nicolazzo, Z. (2014). Teaching the history of higher education: A critical duoethnography. Paper presented at the meeting of the American Educational Research Association, Philadelphia, PA.

Marx, G. (2006). Sixteen trends, their profound impact on our future: Implications for students, education, communities, countries, and the whole of society. Bethesda, MD: Editorial Projects in Education.

McLaren, P. (1995). Critical pedagogy and predatory culture in a postmodern world. New York, NY: Routledge.

North, C. E. (2006). More than words? Delving into the substantive meanings(s) of "social justice" in education. Review of Educational Research, 76(4), 507-535.doi: I0.3102/00346543076004507

Okin, S. (I990). Justice, gender, and the family. Columbia Law Review, 9o(4), II7I-II74.

Paul VI. (1965, December 7). Gaudium et spes. Retrieved from http://www.vatican.va/archive/ hist councils/ii vatican council/documents/vat-ii const 19651207 gaudium-et-spes en.html

Pieper, J. (2003). The four cardinal virtues: Prudence, justice, fortitude, temperance. Notre Dame, IN: University of Notre Dame Press.

Rawls, J. (1999). A theory of justice (Rev. ed.). Cambridge, MA: Harvard University Press. (Original work published 1971)

Rhoads, R., \& Valadez,J. R. (1996). Democracy, multiculturalism and the community college: A critical perspective. New York, NY: Routledge.

Sacks, P. (1999). Generation $X$ goes to college: An eye-opening account of teaching in postmodern America. Chicago, IL: Open Court.

Shaw, K. Valadez, J. R. \& Rhoads, R. (1999). Community colleges as cultural texts: Ethnographic explorations of organizational culture. Albany, NY: State University of New York Press.

Schön, D. 1983). The reflective practitioner: How professionals think in action. London, UK: Temple Smith.

Shor, I. (1992). Empowering education: Critical teaching for social change. Chicago, IL: The University of Chicago Press.

Sleeter, C. (20or). Preparing teachers for culturally diverse schools: Research and the overwhelming presence of whiteness. Journal of Teacher Education 52(2), 94106. doi: Io.II77/0022487101052002002 
St. John, E. (1999). Integrating liberation theory into restructuring: Toward a model for urban Catholic schools. Catholic Education: A Journal of Inquiry and Practice, 2(3), 265-280.

Taylor, C. (2007). A secular age. Cambridge, MA: Harvard University Press.

Terrell, R. D., \& Lindsay, R. B. (2009). Culturally proficient leadership: The personal journey begins within. Thousand Oaks, CA: Corwin.

United States Conference of Catholic Bishops (USCCB) (n.d.). Seven themes of Catholic social teaching. Retrieved from http://www.usccb.org/beliefs-and-teachings/what-webelieve/catholic-social-teaching/seven-themes-of-catholic-social-teaching.cfm

United States Conference of Catholic Bishops (1986). Economic justice for all: Pastoral letter on Catholic social teaching and the U.S. economy. Retrieved from http://www.usccb.org/ upload/economic justice for all.pdf

United States Conference of Catholic Bishops (1996). A Catholic framework for economic life: A statement of U.S. Catholic bishops. Retrieved from http://www.usccb.org/issues-andaction/human-life-and-dignity/economic-justice-economy/catholic-framework-foreconomic-life.cfm

Valadez,J. R. (2000). Searching for a path out of poverty: Exploring the achievement ideology of a rural community college. Adult Education Quarterly, 5O(3), 2I2-229. doi: I0.II77/074171300220870I7

Valadez, J. R. (2008). Shaping the educational decisions of Mexican immigrant high school students. American Educational Research Journal, 45(4), 834-86o. doi: I0.3102/0002831208320244

Van Kersbergen, K. (1995). Social capitalism: A study of Christian democracy and the welfare state. New York, NY: Routledge.

Wolff, J. (2002). Addressing disadvantage and the human good. Journal of Applied Philosophy, I9 (3), 207-218. doi: 10.IIII/I468-5930.toI-I-002I6

Young, R. (1990). A critical theory of education: Habermas and our children's future. New York, NY: Teachers College Press.

James $R$. Valadez is a professor of education at the University of Redlands. He specializes in the sociology of education, research methods, and program evaluation. Correspondence regarding this article can be sent to Dr. Valadez at jamesvaladez@redlands.edu

Philip S. Mirci is a Roman Catholic deacon for the Diocese of San Bernardino and an associate professor of education at the University of Redlands. He teaches courses in the doctoral, counselor, and administrator preparation programs. 